\title{
A comparison of perennial ryegrass cultivars differing in heading date and grass ploidy with spring calving dairy cows grazed at two different stocking rates
}

\author{
Michael O’DONOVAN ${ }^{\mathrm{a}}$, Luc DELABY ${ }^{\mathrm{b}}$ \\ a Dairy Husbandry Department, Teagasc, Moorepark Production Research Centre, Fermoy, \\ Co. Cork, Ireland \\ b INRA, UMR Production du Lait, 35590 St Gilles, France
}

(Received 16 March 2004; accepted 23 May 2005)

\begin{abstract}
Milk production systems in Ireland are based on the efficient conversion of grazed grass to milk. Increasing cow performance at pasture maybe possible with the use of grass cultivars better suited to the system. The objective of this study was to examine the effects on milk production performance, dry matter intake and sward characteristics of grass cultivars with contrasting heading date (HD; intermediate or late) and grass ploidy (PL; diploid or tetraploid) when grazed at two different stocking rates (SR; low or high), according to a $2 \times 2 \times 2$ factorial design. The study took place over a 2 year period. Eighty Holstein spring calving cows were balanced into eight individual groups (10 cows per treatment) and were assigned randomly to one of eight grazing treatments. The stocking rate imposed from April to early June in year 1 was 4.8 and 4.3 cows per ha for high and low stocking rates and 3.9 and 3.5 cows per ha for the remainder of the study. Stocking rates imposed in year 2, were 5.1 and 4.2 cows per ha from April to early June and 4.3 and 3.5 cows per ha thereafter. The experiment began in April and finished in late September in both years. On average during the two years $144 \mathrm{~kg}$ concentrate per cow was offered. Cows grazing late HD cultivars had significantly $(P<0.01)$ higher milk yield, lactose concentration and solid corrected milk yield $(P<0.09)$. Cows grazing at low SR had significantly $(P<0.001)$ higher milk, solid corrected milk, fat, protein, lactose yield and concentration and bodyweight than cows grazing at the high SR. Grass dry matter intake (GDMI) was significantly higher $(1.0 \mathrm{~kg}, P<0.001)$ for cows grazing late HD cultivars. Cows grazing at the lower SR had significantly $(+1.2 \mathrm{~kg}, P<0.001)$ higher GDMI. Late HD cultivars produced swards with higher ingestibility, better digestibility coefficients, sward characteristics and grass quality. These improvements in sward quality allowed cows grazing later heading cultivars to improve their milk production performance.
\end{abstract}

dairy cows / grass cultivars / stocking rate / intake

Résumé - Influence de la date d'épiaison et de la ploïdie de variétés de ray-grass anglais sur les performances des vaches laitières au pâturage conduit à deux niveaux de chargement. En Irlande, les systèmes de production laitière reposent sur une utilisation optimale de l'herbe pâturée.

* Corresponding author: maodonovan@ moorepark.teagasc.ie 
L'amélioration des performances au pâturage doit être possible grâce à l'utilisation de variétés bien adaptées à ces systèmes. L'objectif de cette expérience était de quantifier l'effet de quatre variétés de ray-grass anglais pâturées à deux niveaux de chargement sur les caractéristiques de l'herbe, les quantités ingérées et la production des vaches laitières. Cette expérience a été réalisée au cours de deux années consécutives. Les variétés ont différé à la fois par leur date d'épiaison (intermédiaire et tardive) et leur ploïdie (diploïde et tétraploïde) et les deux niveaux de chargement ont été appliqués sur chacune des variétés étudiées. Chaque année, 80 vaches laitières Holstein vêlant au printemps ont été réparties en 8 lots et affectées à l'une des huit combinaisons de traitements. En année 1, les chargements ont été de 4,8 et 4,3 vaches par hectare entre avril et début juin puis de 3,9 et 3,5 jusqu'en septembre, respectivement pour les niveaux haut et bas. Lors de l'année 2, ils ont été de 5,1 et 4,2 vaches par hectare entre avril et début juin puis de 4,3 et 3,5 en automne. En moyenne sur les deux années, les vaches ont reçu $144 \mathrm{~kg}$ de concentré durant la saison de pâturage. Les variétés tardives ont permis de produire significativement plus de lait, plus de lait $4 \%$ avec une teneur en lactose plus élevée $(P<0,01)$. Les vaches affectées au chargement bas ont produit significativement plus de lait, de lait $4 \%$, de matières grasses, de protéines et de lactose $(P<0,001)$. La teneur en lactose de leur lait ainsi que leur poids vif ont été également plus élevés. Les quantités d'herbe ingérées ont été supérieures $(+1,0 \mathrm{~kg}, P<0,001)$ sur les variétés tardives et chez les vaches du chargement bas $(+1,2 \mathrm{~kg}, P<0,001)$. Finalement, les variétés à épiaison tardive produisent une herbe plus ingestible, avec des caractéristiques plus favorables en terme de digestibilité. L'amélioration de ces caractéristiques chez les variétés tardives a permis alors d'accroître les performances laitières des vaches.

vaches laitières / pâturage / variétés / production laitière / ingestion

\section{INTRODUCTION}

The production and utilisation of grass has a central role in maintaining the competitiveness of the Irish dairy industry. Much of the focus of grassland research has centred on grass production [21] and grass utilisation [34]. Plant breeding has contributed a $4-5 \%$ increase in dry matter (DM) production and an increase of $10 \mathrm{~g}$ per $\mathrm{kg}$ in DM digestibility per decade in North Western Europe since the 1950's [43]. Animal productivity is the ultimate measure of the worth of any new grass cultivar. However direct assessment is complex and expensive [13].

Recent research has identified a number of important sward factors that influence intake and milk production. The most important factor appears to be green leaf mass [31]. Grass variety can have a major influence on the production of green leaf mass [16], especially cultivars with different heading dates [15]. Gately [12] completed a comparison of grass cultivars for milk production and showed that the effect of cultivar (early versus late heading date [HD]) depended on the stocking rate (SR) imposed. Gowen et al. [15] showed that late
HD cultivars supported a higher level of performance than intermediate HD cultivars when compared with a similar grazing management approach. Currently tetraploid cultivars constitute approximately 35 to $40 \%$ of all Irish grass mixtures [5]. Therefore their inclusion in mixtures will increase given the potential of the late HD tetraploids currently recommended in grass variety lists. It could be argued that different grass cultivars require varying grazing management strategies [14]. Even so, it is interesting to quantify and understand the role of cultivars in the optimisation of animal production in terms of milk or meat. The objective of this study was to investigate the effects on milk yield and composition, grass intake and sward characteristics of grass cultivars with contrasting HD and grass ploidy (PL) when grazed at different SR.

\section{MATERIALS AND METHODS}

\subsection{Site characteristics}

The experiment was carried out at the Moorepark Research Centre, Fermoy, Co 
Cork (lat. $50^{\circ} 07^{\prime} \mathrm{N}$, long. $08^{\circ} 16^{\prime} \mathrm{W}$ ) during the grazing season of 2001 (year 1) and 2002 (year 2). The following perennial ryegrass cultivars were sown as monocultures: Millenium (late - June 10th, tetraploid), Portstewart (late - June 7th, diploid), Napoleon (intermediate - May 20th, tetraploid) and Spelga (intermediate - May 17th, diploid). Approximately 11.2 ha were sown by complete direct drilling with the remaining 6 ha by direct sowing after deep ploughing in August, 1998. A further 3.9 ha of the experimental area was reseeded by direct sowing in April 2000. The seeding rate was $42 \mathrm{~kg}$ per ha for tetraploids and $34 \mathrm{~kg}$ per ha for diploids.

\subsection{Design and layout}

The design of this study was a $2 \times 2 \times 2$ factorial arrangement of treatments. Four cultivars consisting of two HD and two PL were compared at two grazing stocking rates. There were twelve paddocks for each grass cultivar. Paddock size ranged from 0.17 to 0.24 ha for the high SR treatment and from 0.21 to 0.29 ha for the low SR treatment.

\subsection{Animals and supplementation}

Eighty spring calving cows (mean calving date, February 17) were used in the study. All multiparous animals were used in year 1, 8 multiparous and 2 primiparous animals per treatment were used in year 2 . The cows were blocked into groups of 8 (10 cows per treatment) on the basis of lactation number (mean and standard deviation) 3.6 \pm 0.67 , days in milk $43.9 \pm 8.60$ days, previous 3 weeks pre experimental milk yield (kg milk cow per day) $34.2 \pm 3.29$ and mean liveweight $(\mathrm{kg}) 546 \pm 38.9$. Within each block, animals were randomly assigned to treatments. In year 2, mean lactation number of the cows used was $3.6 \pm 1.53$, days in milk was $43.3 \pm 13.34$, pre experimental milk yield for the previous two weeks was $33.9 \pm 6.1 \mathrm{~kg}$ per cow and mean bodyweight was $547 \pm 72.8 \mathrm{~kg}$. The animals had access to grass day and night and were supplemented with $7 \mathrm{~kg}$ concentrate per cow per day during the pre-experimental periods in both years.

All concentrates were offered in individual stalls (Dairymaster, Causeway, Co. Kerry) in the milking parlour in two equal feeds daily. The ingredient composition $(\mathrm{kg}$ per $\mathrm{t})$ of the concentrate was barley 250, unmolassed beet pulp 250, corn gluten feed 250, rapeseed meal 100, soya bean meal 100 , fat 20 and minerals and vitamins 30 . In year 1 , the cows were offered $2.6 \mathrm{~kg}$ per concentrate per day from April 2 to May 30 and $0.4 \mathrm{~kg}$ from then until July 4 . Total amount of concentrate offered was $164 \mathrm{~kg}$ per cow. In year 2, a total of $2.9 \mathrm{~kg}$ per day was offered from April 1 to May 9. The total amount of concentrate offered was $113 \mathrm{~kg}$ per cow. The chemical composition of the offered concentrate in year 1 was: Dry matter (DM) 921 g per kg (s.d. 1.3); Ash $107 \mathrm{~g}$ per kg (s.d. 5.6); neutral detergent fibre (NDF) $235 \mathrm{~g}$ per kg (s.d. 17.4); crude protein (CP) $192 \mathrm{~g}$ per kg (s.d. 13.9) and crude fibre (CF) $103 \mathrm{~g}$ per kg (s.d. 4.7). The chemical composition of the offered concentrate in year 2 was: DM $913 \mathrm{~g}$ per $\mathrm{kg}$ (s.d. 1.3); Ash 101 g per kg (s.d. 6.2); NDF 236 (s.d. 18.8); CP 180 (s.d. 8.8) and CF 93 (s.d. 8.1).

\subsection{Sward measurements}

Pre grazing herbage mass above $40 \mathrm{~mm}$ was determined three times a week (Monday, Wednesday and Friday) by cutting four random strips in the paddocks with an Agria motor scythe ( $0.69 \mathrm{~m}$ wide, 5 to $6 \mathrm{~m}$ long). The grass from each strip was weighed, sampled and a sub sample was dried overnight at $95{ }^{\circ} \mathrm{C}$ for DM determination. The remaining herbage from the four strips was bulked and sub samples were taken. Morphological separation took place on a sub sample (ca.120-140 g) of the Monday harvest sample. Samples from the three days harvests were bulked for each week, stored in a freezer at $-20^{\circ} \mathrm{C}$ and later freeze-dried and used for chemical analysis. Herbage samples, representative of that selected by 
the cows (following close observation of grazing animals) were manually collected weekly. Pre grazing and post grazing sward surface height were determined in all paddocks for all rotations. The HFRO (Hill Farming Research Organisation) sward stick was used and 30 measurements were recorded in each paddock.

Approximately $40 \mathrm{~g}$ of the weekly sample was separated into leaf, stem and dead fractions. Each separated sample of live leaf, live stem and dead material was dried overnight at $95^{\circ} \mathrm{C}$ and the results expressed as a proportion of total dry matter. Sward bulk density $\left(\mathrm{kg}\right.$ per $\mathrm{m}^{3}$ ) was determined by dividing herbage mass by pregrazing grass height minus $40 \mathrm{~mm}$ (Agria cutting height). Grass removed (kg DM cow per day) is a measure of the disappearance of grass from each treatment during the grazing period. It was calculated by the following method: [(pre grazing grass height - post grazing grass height / bulk density / area grazed per cow/day)/10000].

\subsection{Animal measurements}

Cows were milked twice daily at 0700 and $1600 \mathrm{~h}$. Milk yield was recorded at each milking. Fat, protein and lactose concentration was determined on one successive morning and evening sample per week using a Fos-let instrument (Foss Electric, DK 3400 Hillerod, Denmark). Solids corrected milk was calculated using the equation [40]. Bodyweight was recorded weekly using a portable weighing scales and Winweigh software package. The animals were assessed for condition score every 2 weeks. Body condition score was measured on a scale of 1 to 5 (where $1=$ emaciated, $5=$ extremely fat) with increments of 0.25 [22].

Individual animal intake was measured on all cows on two occasions in year 1 and four occasions in year 2 using the n-alkane technique of Mayes et al. [25], as modified by Dillon and Stakelum [9]. The dietary organic matter (OM) digestibility coefficients were estimated from the concentra- tion of $\mathrm{C}_{35}$ (pentatriacontane) n-alkane in both feed and faeces of each cow [10], assuming a faecal recovery of 0.90 [8]. The alkane concentration of the dosed pellets, faeces, herbage and concentrate were determined as described by Dillon [8]. In year 1, intake measurements were completed during rotation $3(21 / 5-26 / 5)$ and rotation 5 (9/7-14/7). In year 2, intake measurements were completed during rotation 3 (13/5$18 / 5)$, rotation $5(1 / 7-6 / 7)$, rotation $6(12 / 8-$ $17 / 8)$ and rotation 8 (9/9-14/9).

\subsection{Laboratory procedures and analysis}

The freeze-dried pre-grazing herbage samples were analysed for residual moisture at $103{ }^{\circ} \mathrm{C}$ and incinerated at $550{ }^{\circ} \mathrm{C}$ for 16 hours in a muffle furnace to determine the ash content. Neutral detergent fibre was determined using procedures as outlined by Ankom Technology Corporation (NY, USA). The neutral detergent cellulase digestibility was determined by the method of Morgan and Stakelum [29] as modified by Morgan et al. [30] and CP as outlined by Sweeney [37].

\subsection{Statistical analysis}

All statistical analysis was carried out using SAS [36]. All sward chemical analysis measurements were analysed using analysis of variance model. The model used had terms for year, heading date, grass ploidy, stocking rate and the interactions of these terms.

Individual daily milk and solid corrected milk yields, milk composition, body weight and body condition score were analysed using covariate analysis with terms for year, HD, PL, SR and the interactions of these terms and with the appropriate pre-experimental milk production or bodyweight variable and days in milk as covariates.

All individual grass intake and dietary digestibility values were averaged for both years and were analysed by covariate analysis with terms for year, heading date, grass 
ploidy, stocking rate and the interactions of these terms with the pre-experimental milk yield value and days in milk as covariates.

Multiple regression relationships were derived to explain dry matter intake (DMI) (dependent variable) from pre-experimental milk yield, pre-experimental bodyweight and the effects of heading date, grass ploidy and stocking rate.

Eight cows were removed from the analysis in year 1, because of a disease outbreak. One cow was removed from the analysis in year 2 because she failed to fully recover from a health problem.

\section{RESULTS}

\subsection{Weather}

Total rainfall for year 1 was $854 \mathrm{~mm}$ and $1200 \mathrm{~mm}$ for year 2, compared to the 23 year average (1977-2000) of $1000 \mathrm{~mm}$. However the reduced rainfall did not affect grass growth. Duration of sunshine was 1380 and 1217 hours in year 1 and 2 respectively, compared to 1297 hours for the 23 year average. Mean daily temperature $\left({ }^{\circ} \mathrm{C}\right.$ ) was 10.1 and 10.2 for year 1 and 2 , respectively, which was similar to the 23 year average of $10.0\left({ }^{\circ} \mathrm{C}\right)$.

\subsection{Grazing management}

The experiment began in early April in both years and finished in late September, lasting 8 rotations. Rotation length was the same for all treatments. Mean rotation length was 19 days (s.d. 3.5) in year 1 and 22 days (s.d. 1.7) in year 2. Average residency time for the herds was 2 days over the experimental period. The stocking rate imposed from April to early June in year 1 was 4.8 and 4.3 cows per ha for high and low stocking rates and 3.9 and 3.5 cows per ha for the remainder of the study. Stocking rates imposed in year 2 were 5.1 and 4.2 cows per ha from April to early June and 4.3 and 3.5 cows per ha thereafter. No pasture topping took place in year 1 . In year 2 ,
1 paddock from each treatment was harvested for round baled silage and 2 paddocks from each treatment were topped during rotation three. Nitrogen fertiliser was applied in mid January with $63 \mathrm{~kg} \mathrm{~N}$ per ha, thereafter $50 \mathrm{~kg} \mathrm{~N}$ per ha was re applied after each grazing. No $\mathrm{P}$ and $\mathrm{K}$ fertiliser was applied as soil had adequate levels of these nutrients (based on soil test results).

\subsection{Sward measurements}

Year had an effect on a number of sward parameters, most of these effects are not important, they are therefore not discussed. The effects of HD, PL and SR and their interactions on sward and chemical parameters are shown in Table I. All of the presented results are significant at the $(P<0.05)$ level or less.

\subsubsection{Pre grazing herbage mass and sward height}

Herbage mass and sward bulk density was significantly $(P<0.001)$ affected by HD, PL and SR. There was a significant interaction $(P<0.05)$ between HD and PL; the intermediate HD tetraploid cultivar had $-249 \mathrm{~kg}$ DM per ha lower herbage mass than the intermediate HD diploid, the difference between tetraploid and diploid cultivars for the late HD group was $29 \mathrm{~kg}$ DM per ha. Lower stocked swards had significantly higher herbage mass and pre grazing sward height than the high stocked swards $(+1.34 \mathrm{~cm}, P<0.001)$.

\subsubsection{Sward morphology}

HD and PL had no significant effect on sward morphology. SR significantly affected leaf and stem proportions, higher stocked swards had more live leaf $(+5 \%, P<0.001)$ and less stem $(-2 \%, P<0.01)$ than lower stocked swards.

\subsubsection{Daily herbage allowance (DHA)}

Daily herbage allowance was significantly affected by HD $(P<0.001)$, PL $(P<0.01)$ and SR $(P<0.001)$. Cows grazing the late 


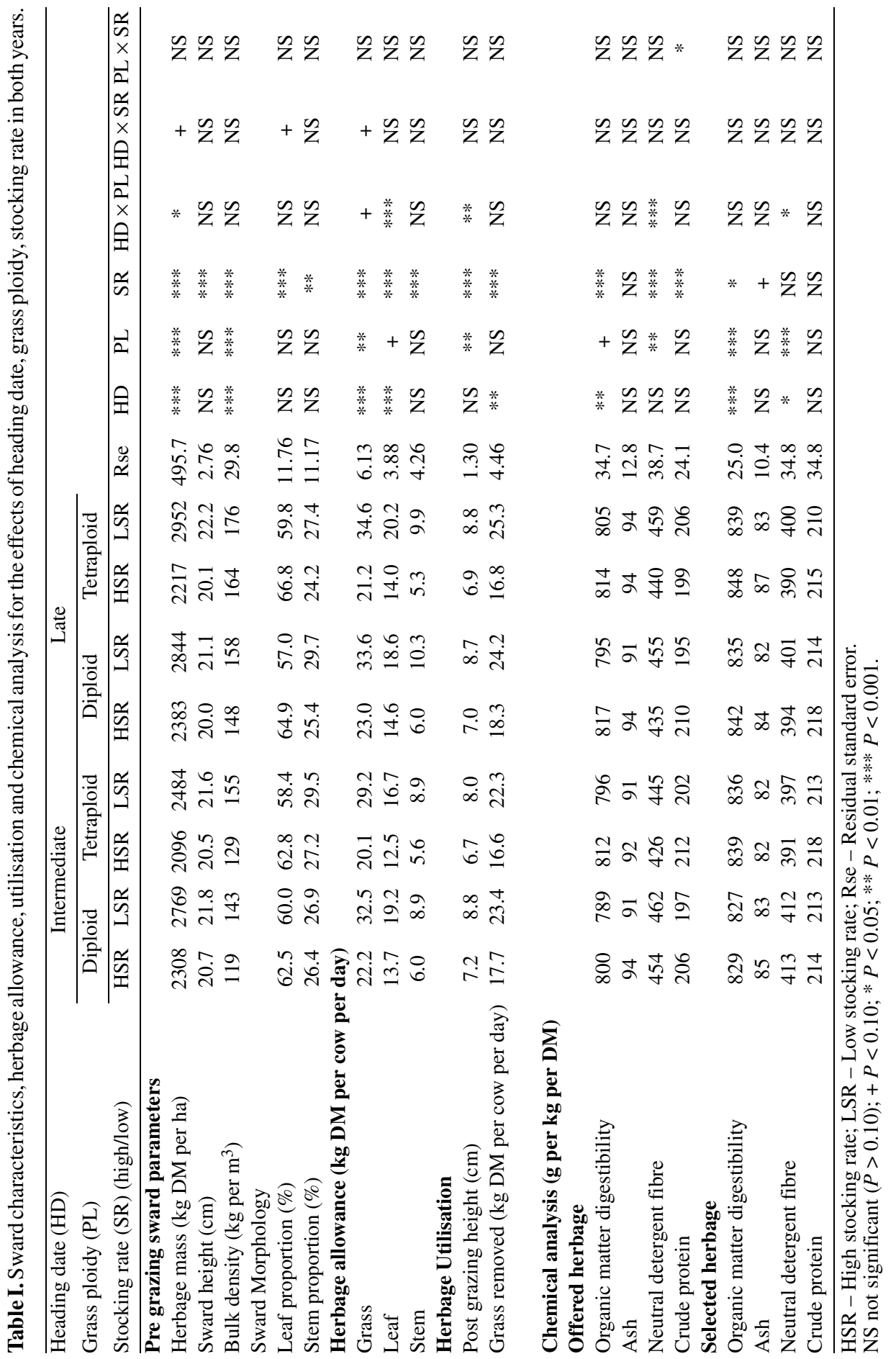


HD cultivars had significantly higher DHA (+2.2 kg DM) compared to cows grazing the intermediate HD cultivar. Cows grazing the diploid cultivars had higher DHA $(+1.5 \mathrm{~kg}$ DM) compared to cows grazing the tetraploid cultivars. Lower stocked cows had higher DHA (+ $10.8 \mathrm{~kg} \mathrm{DM})$ compared to higher stocked cows. There were significant interactions $(P<0.05)$ between HD and PL for DHA and leaf allowance, in both situations this was due to a larger difference in DHA and leaf allowance between the intermediate HD diploid and tetraploid, compared to the late HD diploid and tetraploid. SR $(P<0.001)$ significantly affected stem allowance, cows grazing the LSR had a significantly higher stem allowance (+3.8 kg DM).

\subsubsection{Post grazing sward height and grass removed}

Post grazing sward height was significantly affected by PL $(P<0.01)$ and SR $(P<0.001)$. There was also an interaction between HD and PL $(P<0.01)$. The IH tetraploid had lower post grazing height $(-0.63 \mathrm{~cm})$ than the $\mathrm{IH}$ diploid cultivar. There was no difference in post grazing sward height between the LH cultivars. Mean post grazing sward height was $7.0 \mathrm{~cm}$ for the HSR treatments and $8.5 \mathrm{~cm}$ for the LSR treatments. Grass ploidy $(P<0.01)$ and SR $(P<0.001)$ had a significant effect on the level of grass removed. Grass removed was $6.5 \mathrm{~kg}$ DM higher for the LSR treatments than the HSR treatments (17.4 vs. $23.8 \mathrm{~kg}$ DM per cow per day).

\subsubsection{Herbage chemical composition}

Heading date $(P<0.01)$, PL $(P<0.10)$ and SR $(P<0.001)$ had significant effects on offered herbage digestibility. Late HD $(+8.6 \mathrm{~g}$ per $\mathrm{kg} \mathrm{DM})$, tetraploid $(+6.6 \mathrm{~g}$ per $\mathrm{kg} \mathrm{DM})$ and the higher SR treatments had (+14.4 g per kg DM) higher offered herbage digestibility than IH, diploid and LSR treatments, respectively. Lower stocked swards had significantly $(+16.4 \mathrm{~g}$ per $\mathrm{kg} \mathrm{DM}$,
$P<0.001)$ higher NDF content than HSR swards. There was a significant interaction between HD and PL $(P<0.001)$ for NDF content. The IH tetraploid sward had $(-23 \mathrm{~g}$ per kg DM) lower NDF content than the IH diploid swards. While the LH tetraploid swards had ( $+4 \mathrm{~g}$ per $\mathrm{kg}$ DM) higher NDF than the LH diploid sward.

There was an interaction between PL and SR $(P<0.05)$ for offered sward crude protein content. Selected herbage digestibility was significantly affected by $\mathrm{HD}(P<0.001)$, PL $(P<0.001)$ and SR $(P<0.05)$. Late heading cultivars had $(+8.1 \mathrm{~g}$ per $\mathrm{kg} \mathrm{DM})$ higher digestibility than intermediate HD cultivars. Tetraploid cultivars had $(+7.3 \mathrm{~g}$ per kg DM) higher selected herbage digestibility than diploid cultivars. Lower stocked cows selected herbage of higher quality $(+5.3 \mathrm{~g}$ per $\mathrm{kg} \mathrm{DM})$ than cows grazing at the HSR. HD and PL significantly $(P<0.05)$ interacted for selected herbage NDF. Cows grazing the $\mathrm{IH}$ tetraploid sward selected herbage $(+18.7$ g per $\mathrm{kg}$ DM) higher in NDF compared to the cows grazing the IH diploid sward. There was a (2.8 g per kg DM) difference in NDF between the LH tetraploid and diploid swards.

\subsection{Milk yield, composition, bodyweight and body condition score}

Cows grazing the LH cultivars had significantly higher milk yield $(+0.8 \mathrm{~kg}$ per cow per day, $P<0.01$ ), lactose concentration $(+0.61 \mathrm{~g}$ per $\mathrm{kg})$ and higher solid-corrected milk yield (SCM: $+0.5 \mathrm{~kg}, P<0.10$ ) compared to cows grazing IH cultivars (Tab. II). This effect is due mainly to a larger difference $(P<0.10)$ at LSR $(+1.3 \mathrm{~kg})$ than on the HSR $(+0.3 \mathrm{~kg})$. Cows grazing at the LSR had significantly higher $(P<0.001)$ milk yield $(+1.9 \mathrm{~kg}$ per cow per day), $\mathrm{SCM}$ $(+1.44 \mathrm{~kg})$, fat yield $(+0.062 \mathrm{~kg})$, protein yield $(+0.067 \mathrm{~kg})$, lactose yield $(+0.06 \mathrm{~kg})$ and lactose concentration $(+0.61 \mathrm{~g}$ per $\mathrm{kg})$ than cows grazing at the HSR. Heading date $(P<0.10)$ and grass ploidy $(P<0.10)$ approached significance for protein yield, 
cows grazing $\mathrm{LH}(+0.022 \mathrm{~kg})$ and tetraploid $(+0.02 \mathrm{~kg})$ cultivars had higher milk protein yield than their comparative herds.

Cows grazing at the LSR had significantly $(+13.6 \mathrm{~kg}, P<0.001)$ higher BW than HSR cows. The interaction between HD and PL approached significance $(P<0.10)$ for $\mathrm{BW}$. Cows grazing the IH tetraploid had lower BCS (0.06) than the cows grazing the IH diploid, there was no difference in BCS between cows grazing the LH swards.

\subsection{Intake and diet digestibility}

Table III shows the grass dry matter intake (GDMI) and diet digestibility coefficients for the main factors and their interactions. Cows grazing LH cultivars had significantly $(+1.0 \mathrm{~kg}, P<0.001)$ higher GDMI than cows grazing IH cultivars. Lower stocked cows had significantly higher $(+1.2 \mathrm{~kg}, P<0.001)$ GDMI than the cows grazing at the high stocking rate. The interaction between $\mathrm{HD} \times \mathrm{PL}$ and $\mathrm{HD} \times \mathrm{SR}$ for GDMI approached significance. The interaction between $\mathrm{HD} \times \mathrm{PL}$ was due to the higher GDMI $(+0.9 \mathrm{~kg})$ of the cows grazing the LH tetraploid compared to the LH diploid, there was no difference in GDMI between the two intermediate cultivars. At the high SR, the cows grazing the LH cultivar had $1.6 \mathrm{~kg}$ higher GDMI than the cows grazing the IH cultivars, while at the LSR, the cows grazing the LH cultivars had $+0.72 \mathrm{~kg}$ GDMI than the cows grazing the IH cultivars.

Similar significant effects were recorded for total dry matter intake (TDMI) as for GDMI. Heading date and PL interacted significantly $(P<0.001)$ for DMD and OMD, in addition PL and SR interacted significantly $(P<0.01)$ for DMD. There was a 4 unit digestibility difference in OMD and DMD between the IH tetraploid and diploid cultivars, but there was no digestibility difference between the LH cultivars. There was no difference in DMD between the different stocking rates for the diploid cultivars, however there was a 0.12 unit digestibility difference between low and high SR for the tetraploid cultivars.

\section{DISCUSSION}

Gowen et al. [15] compared the same cultivars to those of the present study. However, in that study, the comparisons were done at one stocking rate, with a flexible grazing management approach. The strategy of maintaining similar grass supply for all cultivars was achieved using extra cows as grazers for short periods with the main herds, during periods of irregular grass supply. When evaluating grass cultivars with differing heading dates, it is difficult to control the variation in grass DM production. This study applied two grazing stocking rates to each cultivar. The objective of this approach was to capture possible milk production differences between the grass cultivars arising from different grazing intensities.

\subsection{Sward canopy characteristics}

A feature of this study was the consistently higher herbage mass production of the late HD and diploid cultivars when compared to their counterparts. This may be related to the lower DM production of the IH tetraploid cultivar. Diploid cultivars had higher bulk density, which agrees with the findings of $[13,15,38]$. The structure of the sward canopy is known to influence grass DMI. Pre grazing sward height and bulk density are recognised as major factors affecting intake [11, 17, 27]. Laca et al. [19] found when sward height was constant between swards, grazing cattle had greater intake per bite with high sward density. Woodward [44] suggests that consideration of these factors alone oversimplifies the sward effects and is insufficient to predict the grass intake ability of swards. The results of this study show significant differences between cultivars in sward structural characteristics and as a general guide the larger the values, the more favourable is the 
cultivar for promoting high grazing performance.

Sward digestibility changes are most often associated with several sward structural changes such as mass, height, content and distribution of the different morphological components within the canopy. The effects of grass digestibility and quantity of easily harvestable material operate at the same time. Late HD cultivars had lower extended tiller height, pseudostem height, lowest ligula height and higher free leaf lamina proportions at particular times during the grazing season (results not shown). These sward canopy differences between intermediate and late HD cultivars were largest during the May/June period. Consistent with the improved sward structure LH cultivars had higher digestibility coefficients. Peyraud et al. [33] found for each 1 unit increase in grass digestibility grass intake increased by $0.20 \mathrm{~kg}$ DM. Herbage consumed by grazing animals usually contains a higher nutrient value than the sward as a whole (Tab. I) [18, 28]. L'Huillier et al. [23] found that the nutrient content of the selected herbage was closely related to the degree of defoliation. As animals graze down through the sward, selectively removing leaf in preference to stem and dead material [42], they change both the structure and composition of the sward. Mayne and Wright [26] indicated that differences in diet selected by animals grazing swards in a vegetative stage, reflect the composition of the grazed horizon rather than any active selection by the animal.

\subsection{Milk yield and grass dry matter intake}

Cows grazing LH cultivars had a higher milk yield $(+3 \%)$ than cows grazing IH cultivars over the study. There was no difference in milk yield between cows grazing intermediate and late heading grass cultivars at the high stocking rate. However at the low SR, cows grazing the LH cultivar had $5 \%$ higher milk production. In a two year study Gowen et al. [15] reported that cows grazing LH cultivars had higher milk yields $(+4 \%$, year $1 ;+6 \%$, year 2$)$ compared to cows grazing IH cultivars, that study was executed at a similar SR to the low SR of this study. Gately [12] reported in a five year grazing experiment that, at a low SR, cows produced $11,14,10,8$ and $3 \%$ more milk when grazing a LH cultivar (Melle, heading date, June 11) than an early HD cultivar (Cropper, heading date May 14). At higher stocking rates, the result was reversed, cows grazing the early HD cultivar produced $8,14,7,5$ and $0.4 \%$ more milk compared to cows grazing the LH cultivar.

Adopting a strategy of increasing SR to graze IH cultivars did not increase milk production performance. This suggests that the milk production performance achieved by LH cultivars is equally as effective at the high stocking rate.

Many short term studies have shown advantages in animal performance with tetraploid cultivars. Castle and Watson [4], Lantinga and Groot [20] found a milk production advantage with tetraploids compared to diploid cultivars. Tas et al. [39] found no difference in milk production between two diploid cultivars. In this study, cows grazing the LH tetraploid cultivar had a consistently higher milk production at both stocking rates, while cows grazing the IH diploid cultivar had lower milk production. The results of this study and Gowen et al. [15] failed to find an effect of PL on milk production performance. However common to both studies was the excellent milk production performance of the LH tetraploid cultivar. It is possible that the poor performance of the IH tetraploid negated the positive milk production effects of the LH tetraploid. The majority of previous studies evaluated tetraploid cultivars over short periods. The extended length of this study may have diluted periodic advantages of tetraploids.

The overall milk yield response to $1 \mathrm{~kg}$ increase in GDMI was $0.66 \mathrm{~kg}$ milk $\left(\mathrm{R}^{2}=\right.$ $81 ; \mathrm{rsd}=2.02 \mathrm{~kg}$ ). Peyraud et al. [34] found in a summary of six experiments that there was a linear response between GDMI and 


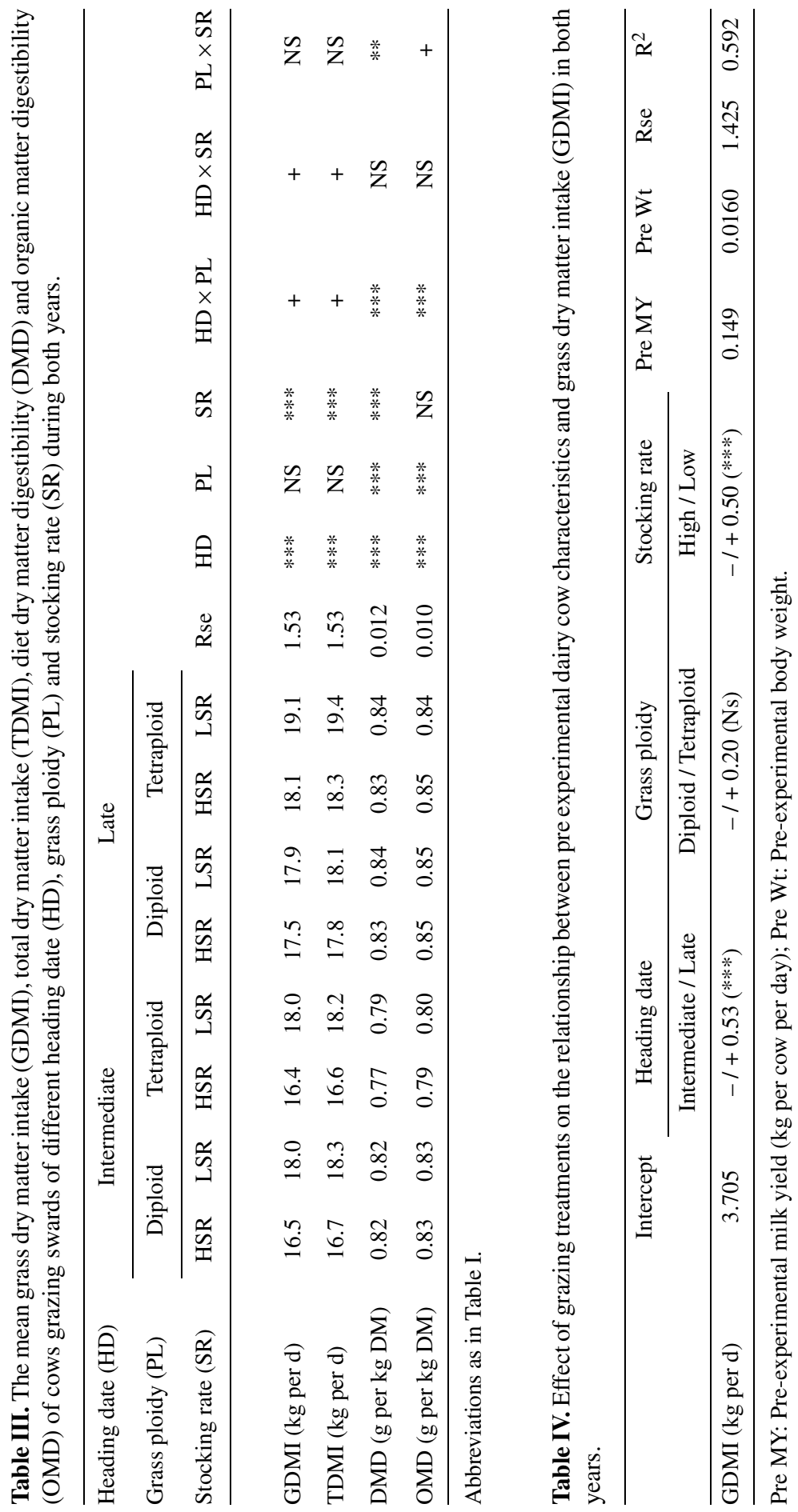


milk yield, each $1 \mathrm{~kg}$ of GDMI resulted in $1 \mathrm{~kg}$ of milk. A sward supporting a high green leaf mass will support a high GDMI [32]. In grazing management studies [7, 31, 35] very close relationships between leaf content and GDMI were found. In this study for each $1 \mathrm{~kg}$ increase in leaf allowance GDMI increased by $0.19 \mathrm{~kg}$. The relationship for DHA was poor, for each $1 \mathrm{~kg}$ increase in grass allowance GDMI increased by only $0.08 \mathrm{~kg}$ DM. When considering DHA $>5 \mathrm{~cm}$, Peyraud et al. [33] observed that with vegetative perennial ryegrass swards, there was an average increase in GDMI of $0.27 \mathrm{~kg}$ DM per $\mathrm{kg}$ increase in DHA when DHA increases between 12 to $17 \mathrm{~kg}$ day and a much smaller increase (+0.05 kg DM day) as DHA increases $>20 \mathrm{~kg}$ day. The overall response for these increases in leaf allowance and DHA are low, however in both cases this study represents the higher end of the response curve. The range in leaf allowance was (10.5-21.5 kg cow per day) and (18.2-44.9 kg DM per cow per day) DHA. A stronger relationship may have been found with a larger range and a lower base point for DHA.

The global analysis of DMI showed it could be predicted using some measures of cow characteristics with HD, PL and SR. The partial regression coefficient for Pre MY (Tab. IV) is within the range of previous data for the prediction of GDMI. The partial regression coefficient of 0.15 increase in GDMI per $\mathrm{kg}$ of Pre MY obtained in the present study is similar to the 0.13 to 0.16 previously observed [2, 6, 24], but was slightly lower than other findings $[3,7,15$, 33]. The regression coefficients of the main effects are significantly different from one another, making the prediction of GDMI difficult. GDMI increased by $1.6 \mathrm{~kg}$ per $100 \mathrm{~kg}$ bodyweight, which is similar to the results reported by Vazquez and Smith [41], but lower than that reported by Gowen et al. [15].

Grass cultivars which produce a high proportion of their swards as green leaf are more likely to increase GDMI and increase milk production performance. This is why cows grazing LH cultivars had better milk production performance than the cows grazing the IH cultivars.

Even though cultivars with different heading dates and grass ploidy were evaluated in this study the main difference between these parameters was the higher overall leaf allowance produced by the later heading cultivars. A realistic goal for grass breeding can be the selection of grass cultivars with the ability to produce leafy swards throughout the season. Combining these cultivars with appropriate grazing management will further improve milk production performance from grass. It is clear from both the current study and [15] that the animal functional parameters are largely unassociated with herbage yield potential (DHA results), which is the main parameter regulating grass evaluation programs and is currently the primary character driving the recommended listing of varieties. It would be better practise if animal value characteristics could be used for testing and selecting cultivars. Green leaf yield could be a major characteristic that could be used to rank cultivars successfully.

\section{CONCLUSIONS}

The results of this study show, at high grazing stocking rates there was no difference in milk output between cows grazing intermediate and late heading grass cultivars, but at the low stocking rate cows grazing the late heading cultivars had 5\% higher milk production than the cows grazing the intermediate heading cultivars. Late heading grass cultivars produced swards with better sward characteristics and digestibility coefficients. These traits allow cultivars to produce a higher green leaf allowance resulting in higher milk production per cow. There was no clear advantage found with tetraploid cultivars compared to diploids to improve milk performance at grazing. Achieving high milk output from grazing dairy cows is an objective of all grassland 
farmers and is particularly important in a milk quota restricted production system. The use of later heading grass cultivars is an avenue of increasing grass intake and milk output from pasture.

\section{ACKNOWLEDGEMENTS}

The authors wish to thank the technical and farm staff of Moorepark Dairy Production Department for their skilled technical assistance. The support of Irish Dairy farmers (Dairy Levy Fund) is acknowledged with gratitude. This research was part-funded by European Union Structural Funds (EAGGF).

\section{REFERENCES}

[1] Baker A.M.C., Leaver J.D., Effect of stocking rate in early season on dairy cow performance and sward characteristics, Grass Forage Sci. 41(1986) 333-340.

[2] Bines J.A., Napper D.J., Johnson V.W., Long term effects of level of intake and diet composition on the performance of lactating dairy cows. 2. Voluntary intake and ration digestibility in heifers, Proc. Nutr. Soc. 36 (1977) 14A (Abstract).

[3] Butler S.B., Stakelum G.K., Murphy J.J., Delaby L., Rath M., O'Mara F.P., The relationship between milk production and herbage intake of grazing dairy cows, Anim. Sci. 77 (2003) 343-354.

[4] Castle M.E. Watson J.N., A comparison between diploid and a tetraploid perennial ryegrass for milk production, J. Agric. Sci. (Camb.) 77 (1971) 69-76.

[5] Connolly V., Breeding Improved Varieties of Perennial Ryegrass, Teagasc Report, ISBN 1 84170,2001

[6] Conrad H.R., Pratt A.D., Hibbs J.W., Regulation of feed intake in dairy cows. 1. Change of importance of physical and physiological factors with increasing digestibility, J. Dairy Sci. 60 (1964) 1725-1733.

[7] Delagarde R., Peyraud J.L., Delaby L., Herbage intake of strip-grazing dairy cows: effects of herbage allowance, concentrate supplementation level and initial milk yield, Proc. 18 Gen. Mtg. Eur. Grld. Fed. AAlborg, 2000, pp. 309-311.

[8] Dillon P., The use of $\mathrm{N}$-alkanes as markers to determine herbage intake, botanical composi- tion of available or consumed herbage and in studies of digesta kinetics with dairy cows, Ph.D. Thesis, N.U.I., 1993.

[9] Dillon P., Stakelum G., Herbage and dosed alkanes as a grass measurement technique for dairy cows, Ir. J. Agric. Res. 28 (1989) 104 (Abstract).

[10] Dove H., Mayes R.W., The use of plant wax alkanes as marker substances in studies of the nutrition of herbivores: A Review, Aust. J. Agric. Res. 42 (1991) 913-952.

[11] Forbes T.D.A., Researching the plant-animal interface: the investigation of ingestive behaviour in grazing animals, J. Anim. Sci. 66 (1988) 2369-2379.

[12] Gately T., Early versus late perennial ryegrass (Lolium perenne) for milk production, Ir. J. Agric. Res. 23 (1984) 1-11.

[13] Gilliland T.J., Barrett P.D., Mann R.L., Agnew R.E., Fearon A.M., Canopy morphology and nutritional traits as potential grazing value indicators for Lolium perenne varieties, J. Agric. Sci. (Camb.) 139 (2002) 257-273.

[14] Gilliand T.J., Camlin M.S., Johnston J., Effect of harvest date and cultivar maturity on perennial ryegrass (Lolium Perenne L.) yield and digestibility, Ir. J. Agric. F. Res. 34 (1995) 133-142.

[15] Gowen N., O’Donovan M., Casey I., Stakelum G., Rath M., The effect of grass cultivars differing in heading date and ploidy on the performance and dry matter intake of spring calving dairy cows at pasture, Anim. Res. 52. (2003) 321-336.

[16] Hageman I.W., Lantinga E.A., Schlepers H., Herbage intake, digestibility characteristics and milk production of some diploid and tetraploid perennial ryegrass cultivars, in: Proc. of 2nd Brit. Grassl. Soc. Res. Conference, Scot. Agric. College, Ayr, 1990, Paper 5.

[17] Hodgson J., Variations in the surface characteristics of the sward and the short term rate of herbage intake by calves and lambs, Grass Forage Sci. 36 (1981) 49-57.

[18] Hodgson J., Grazing behaviour and herbage intake, in: Frame J. (Ed.), "Grazing", Occasional Symposium of the British Grassland Society, Hurley, UK, 1986, No. 19, pp. 51-64.

[19] Laca E.A., Ungar E.D., Seligman N.G., Demment M.W., Effects of sward height and bulk density on bite dimensions of cattle grazing homogeneous swards, Grass Forage Sci. 47 (1992) 91-102.

[20] Lantinga E.A., Groot J.C.J., Optimisation of grassland production and herbage feed quality in an ecological context, EAAP Public., 1996, No. 84, pp. 58-67. 
[21] Lebret C., O'Donovan M., Delaby L., The use of statistical models to forecast grass growth using grass biomass, fertilisation and meterological parameters, Study report, INRA, Saint Gilles, France, 2001

[22] Lowman B.G., Scott N., Somerville S., Condition scoring of cattle, Rev. Edition, Bulletin East Scotland Coll. Agric., 1976, No. 6.

[23] L'Huillier P.J., Poppi D.P., Fraser T.J., Influence of structure and composition of ryegrass and prairie grass white clover swards on the grazed horizon and diet harvested by sheep, Grass Forage Sci. 41 (1986) 259-267.

[24] Maher J., Stakelum G., Rath M., Effect of daily herbage allowance on the performance of spring calving dairy cows, Ir. J. Agric. Food Res. 42 (2003) 229-241.

[25] Mayes R.W., Lamb C.S., Colgrove P.A., The use of dosed herbage n-alkanes as markers for the determination of herbage intake, J. Agric. Sci. 107 (1986) 161-170.

[26] Mayne C.S., Wright I.A., Herbage intake and utilisation by grazing dairy cows, in: Garnsworthy P.C. (Ed.), Nutrit. and Lact. in the Dairy Cow, Butterworths, London, 1988.

[27] McGilloway D.A., Mayne C.S., The importance of grass availability for the high genetic merit cow, in: Garnsworthy P.C., Wisemand J., Haresign W. (Eds.), Recent advances in Animal Nutrition, Nottingham University Press, Nottingham, UK, 1996.

[28] Meijs J.A.C., Hoekstra J.A., Concentrate supplementation of grazing dairy cows. II. Effect of concentrate intake and herbage allowance on herbage intake, Grass Forage Sci. 39 (1984) 59-66.

[29] Morgan D.J., Stakelum G., The prediction of digestibility of herbage for dairy cows, Ir. J. Agric. Res. 26 (1987) 23-34.

[30] Morgan D.J., Stakelum G., Dwyer J., Modified neutral detergent cellulase digestibility procedure for use with the 'Fibertec' system, Ir. J. Agric. Res. 28 (1989) 91-92.

[31] Parga J., Peyraud J.L., Delagarde R., Effect of sward structure and herbage allowance on herbage intake by the grazing dairy cows, in: Grazing management, the principles and practise of grazing for profit and environmental gain in temperate grassland system, Harrogate, Brit. Grassl. Soc., 2000.

[32] Penning P.D., Parsons A.J., Orr R.J., Hooper G.E., Intake and behaviour responses by sheep to changes in sward characteristics under rotational grazing, Grass Forage Sci. 49 (1994) 476-486.

[33] Peyraud J.L., Comeron E.A., Wade M.H., Lemaire G., The effect of daily herbage allow- ance, herbage mass and animal factors upon herbage intake by grazing dairy cows, Ann. Zootech. 45 (1996) 201-207.

[34] Peyraud J.L., Gonzalez-Rodrigez A., Relations between grass production, supplementation and intake in grazing dairy cows, in: Proc. Grassl. Farming, balancing environmental and economic demands, Grassland Sci. Eur. 5 (2000) 269-282.

[35] Stakelum G., Dillon P., Influence of sward structure and digestibility on the intake and performance of lactating and growing cattle, in: Mayne C.S. (Ed.), Management issues for the grassland farmer in the 1990's. British Grassland Society Occasional Symposium, 1990, No. 25, pp. 30-42.

[36] Statistics Analysis Systems Institute, User's Guide: Statistics, SAS Institute, Cary, North Carolina, 1991.

[37] Sweeney R.A., Generic combustion method for determination of crude protein in feeds: collaborative study, J. Assoc. Off. Anal. Chem. 72 (1989) 770-774.

[38] Swift G., Vipond J.E., McCelland T.H., Cleland A.T., Milne J.A., Hunter E.A., A comparison of diploid and tetraploid perennial ryegrass and tetraploid ryegrass/white clover swards under continuous sheep stocking at controlled heights. 1. Sward characteristics, Grass Forage Sci. 48 (1993) 279-289.

[39] Tas B.M., Taweel H.Z., Smit H.J., Tamminga S., Dijkstra J., Elgersma A., Intake, digestibility and milk production of dairy cows fed perennial ryegrass cultivars during the season, Grassland Sci. Eur. 7 (2002) 262-263.

[40] Tyrrell H.F., Reid J.T., Prediction of the energy value of milk, J. Dairy Sci. 48 (1965) 1215-1223.

[41] Vazquez O.P., Smith T.R., Factors affecting pasture intake and total dry matter intake in grazing dairy cows, J. Dairy Sci. 83 (2000) 2301-2309.

[42] Van Dyne G.M., Brockington N.R., Szocs Z., Duek J., Ribic C.A., Large herbivore sub-system, in: Breymeyer A.I., Van Dyne G.M. (Eds.), Grasslands, Systems Analysis and Man, Cambridge University Press, Cambridge, 1980, pp. 269-537.

[43] Wilkins P.W., Humphreys M.O., Progress in breeding perennial forage grasses for temperate Agriculture, J. Agric. Sci. 140 (2003) 129150.

[44] Woodward S.J.R., Bite mechanics of cattle and sheep grazing grass-dominant swards, Appl. Anim. Behav. Sci. 56 (1998) 203-222. 